\title{
THE POLITICAL ECONOMY OF OLIGARCHY AND THE REORGANIZATION OF POWER IN INDONESIA
}

\section{Vedi R. Hadiz and Richard Robison}

When three decades of authoritarian rule unravelled in Indonesia following the fall of President Suharto in 1998, it was widely expected that this would also open the doors for a dramatically different sort of politics in which individuals and social organizations could demand accountable governance and rule of law. It was indeed true that the old centralized authoritarian regime gave way to a remarkably open system of electoral democracy and to the devolution of state administrative authority. A vibrant and often chaotic media emerged to debate ideas previously proscribed, and new figures flooded onto the political landscape. And in the volatile period that followed the Asian financial crisis just a few years previously, successive Indonesian governments had been forced to agree to the demands of the IMF (International Monetary Fund) and other global organizations for widespread reforms in finance and banking, in public and corporate governance, and in the judiciary, especially in the commercial courts.

However, such institutional changes were not reflected in the way social and economic power was concentrated or imposed in Indonesia. Well over a decade after the fall of the Suharto regime, access to and control of public office and state authority continues to be the key determinant of how private wealth and social power is accumulated and distributed. Many of the old faces continue to dominate politics and business, while new ones are drawn into the same predatory practices that had defined politics in Indonesia for decades. Even political parties that presented themselves as 
the new champions of good governance, such as the Islamic party, PKS (Partai Keadilan Sejahtera, Prosperous Justice Party), became enmeshed in corrupt practices and dubious alliances. Rather than opening the door for political parties to emerge on the basis of claims to ideological or policy agendas, the same Suharto-era political parties continue to operate as escalators for careers and wealth, even if this function is now shared with some new political vehicles. And far from providing a new dimension of accountability and representation, the decentralization of administrative authority and parliamentary politics has extended the old ways of politics from the political center of Jakarta down to a bewildering range of individuals and organizations in the regions and towns of Indonesia.

In this paper we argue that these seemingly counter-intuitive developments are best analyzed within a structural political economy approach and understood in the context of the vast political conflicts that precede and follow democratic and market transitions and that preserve or reshape the social order that defined the old regime. ${ }^{1}$ In other words, the disintegration of authoritarian rule and the introduction of democratic and market institutions do not in themselves give rise to a broader liberal transformation of society and politics. The forces and interests that had established their preeminence within the previous regime do not necessarily disappear along with the institutions of centralized authoritarian rule. As Nigel Harris has observed, "... when the state establishes a system for forced accumulation, this is not simply a set of arrangements that can be changed at will. It constitutes a social order, with a weight of inertia constituted by vested interests, the immediate beneficiaries, that inhibits the creation of any new order." ${ }^{2}$

The influence of previous authoritarian regimes on new democracies and market economies is also expressed in other ways. As Sheri Berman has reminded us in her analysis of the Arab Spring and of the rise of Fascism in Germany and Italy in the 1920 s and 1930s, the prospects for a coherent liberal politics are diminished where the previous order has disorganized civil society and destroyed liberal forces as part of its formula for rule. ${ }^{3}$ These circumstances can open the door for political chaos or money politics and for the entry of extremist, resentful, and violent political interests that appeal to the basest of xenophobic sentiments. At the very least, such cases show that so-called "transitions" to liberal forms of democracy are likely to be severely impeded where the social interests that support such a transition are weak or politically disorganized.

The central task of this study is to explain how those interests that had established political ascendancy within the previous Indonesian regime have been able to reorganize their power and preserve salient features of the old social and political order within the shell of the new democratic and market society. Specifically, we propose, it has been the rise of a highly cohesive and complex oligarchy that has led to

\footnotetext{
${ }^{1}$ This thesis is most comprehensively set out in Richard Robison and Vedi R. Hadiz, Reorganising Power in Indonesia: The Politics of Oligarchy in an Age of Markets (London: RoutledgeCurzon, 2004). Given that this paper is a development of that thesis, and its defense in the current debate, the arguments in the book are necessarily referred to and repeated.

${ }^{2}$ Nigel Harris, "New Bourgeoisies," The Journal of Development Studies 24,2 (1988): 47.

${ }^{3}$ Sheri Berman, "The Promise of the Arab Spring: In Political Development, No Gain without Pain," Foreign Affairs 92,1 (January/February 2013): 64-74.
} 
these conditions, an oligarchy that embraces both a particular form of dominance over state power and a distinct social and economic character that is the key to the puzzle in Indonesia. ${ }^{4}$ The paper begins with an explanation of what this specific form of oligarchy is and is not, on the basis of a political economy theoretical framework. The aim is to clarify factors that have been often lost in translation between the parallel universes of pluralist liberal political science, rational choice neoliberalism, and critical political economy, and to set a firm basis for debate.

This explanation is followed by an examination of how our thesis is located in the larger terrain of political and political economy analysis of Indonesia in the postSuharto era. In this evaluation, the theoretical focus is more firmly placed on the agency of rational individuals and the transformative capacity of institutions. In the final and largest part of the paper, we provide a detailed analysis of how oligarchy has shaped state authority and social power in contemporary Indonesia and how this system of power has survived and colonized the political and economic upheavals of 1997 and 1998 and remains the defining force in contemporary Indonesia.

\section{The Oligarchy Thesis: What It Is and Is Not}

It is fair to say that the broader debate about the evolution of political power in Indonesia since the fall of Suharto has been largely focused on the critique (or defense) of the oligarchy thesis developed by Richard Robison and Vedi Hadiz and by Jeffrey Winters. Such critiques have included arguments that the oligarchy thesis neglects the possibilities of agency and presents a pessimistic picture of a country caught in a structural straitjacket; that it denies the importance of institutions as mechanisms of change; that it denies the significance of non-material factors in politics; and that it denies the real inroads made by local and grassroots political and social movements in questions of policy, accountability, and representation. ${ }^{5} \mathrm{~A}$ discussion of these critiques requires some brief clarification of the oligarchy thesis, what it argues and what it does not.

\section{The Oligarchy Thesis: What It Is}

Oligarchy is treated here as a system of power relations that enables the concentration of wealth and authority and its collective defense. It is a concept of oligarchy that is set in a larger theoretical framework of structural political economy. Thus, the construction of oligarchy is understood in the context of capitalist

\footnotetext{
${ }^{4}$ See Richard Robison and Andrew Rosser, "Surviving the Meltdown: Liberal Reform and Political Oligarchy in Indonesia," in Politics and Markets in the Wake of the Asian Crisis, ed. Richard Robison, Mark Beeson, Kanishka Jayasuriya, and Hyuk Rae Kim (London: Routledge, 2000), pp. 171-91; and Vedi R. Hadiz, Localising Power in Post-Authoritarian Indonesia: A Southeast Asia Perspective (Stanford, CA: Stanford University Press, 2010). The same broad proposition is made by Jeffrey Winters in his wider historical and comparative analysis of different forms of oligarchy. See Jeffrey Winters, Oligarchy (Cambridge: Cambridge University Press, 2011).

${ }^{5}$ In fact, the rationale for the workshop in Sydney that is the basis of the papers in this collection was to bring such critiques into a direct conversation with the proponents of the idea of oligarchy as an explanatory concept. Critiques, including those above, are found in Pepinsky, Liddle, and Aspinall, all in this special issue.
} 
development, especially as manifested in late developing capitalist countries. The rise of oligarchy in Indonesia at a time of growth and expansion of market capitalism during the New Order is seen as the product of struggles over the accumulation of private and corporate wealth and the way control of public institutions and state authority became essential to this process. This particular fusion of political authority and economic power has been a common characteristic of countries in the earliest stages of capitalist development, as evidenced by cases ranging from the South Sea Bubble and the joint stock scandals of early English capitalism to the "robber barons" of late-nineteenth-century America. This phenomenon has been variously described as "primitive accumulation" or "political capitalism."

Importantly, oligarchy is not conceived as a type of economic or political regime in itself nor tied to any specific form of regime in this analysis. In fact, we propose that oligarchy can survive and flourish in a range of regime types, including democracy, as we currently see in post-Suharto Indonesia. Nevertheless, oligarchies are historically defined. Significantly, for example, a plutocracy cannot rule from outside the apparatus of the state in Indonesia in the same way it does in the United States. This is partly because its biggest players in Indonesia are and have been ethnically Chinese and are therefore constrained in their public political role. It is also because Indonesian capitalism was incubated within the state itself, establishing a distinct relationship between state capitalism and private interest that did not exist in America.

The focus of the analysis is, therefore, on the structural factors that gave rise to a particular form of politico-business oligarchy in Indonesia, specifically on how state authority and bourgeois interest historically evolved, interacted, and became fused during the New Order. It is important that the relationships between state authority and the bourgeoisie in Indonesia changed from a Bonapartist form in the early Suharto era to one that took an oligarchic form in the later New Order period. This was a state that had become the possession of its own officials and that acted to preserve its own institutional underpinnings and on behalf of major capitalist interests. Such a state was transformed to one that was defined by an increasing fusion of wealth and politicobureaucratic power, articulated in the relationships and interminglings between the leading families of business and those of politics and the bureaucracy as they became enmeshed directly in the ownership and control of capital.

Perhaps the most controversial aspect of this treatment of oligarchy is the suggestion that democracy has not undermined the oligarchy that emerged under the New Order, although the theory does acknowledge that Indonesia's dominant elite has been forced to sustain its ascendancy in different ways. For example, oligarchic power in Indonesia now more distinctly accommodates members of the growing apparatus of administration and politics at the local level. Many of these local members have successfully reinvented themselves as parliamentarians and political party leaders and forged new kinds of alliances with local business interests, leaders of mass organizations old and new, and, sometimes, even with military or police commands. Many former political, business, and criminal elements have used the diffusion and decentralization of government to establish quite new political identities. 


\section{The Oligarchy Thesis: What It Is Not and What It Rejects}

\section{a) The Primacy of Institutional Change}

The oligarchy thesis does not dismiss the significance of institutions in influencing political behavior, although it does place primacy on the coalitions of power that underpin them. In other words, we place emphasis on where institutions come from and how they are constructed or expropriated by powerful forces to serve their own needs. ${ }^{6}$ Nevertheless, the thesis does not argue that "nothing has changed in Indonesia." There is little doubt that the "shock therapy" of change in both economic and political institutions after 1998 has meant that entrenched oligarchies and others have to find new ways of surviving and operating within an increasingly globalized market and a democracy that is both decentralized and based on electoral politics. Moreover, it is no longer possible for those holding power to ignore the demands and resentments of social coalitions of interests that may emerge at the local level of politics.

\section{b) Ideas about Indonesian Uniqueness}

The critical political economy approach that infuses the oligarchy thesis refutes exceptionalist or relativist explanations of politics or ideas, including those based on cultural or behavioral factors. One of the key advantages of utilizing the concept of oligarchy within a critical political economy framework is to better enable historically informed comparisons of the Indonesian case with those of others, including countries outside the developing world ${ }^{8}$ Even the case of the United States, where oligarchic power has been a traditional feature of US politics in big cities as well as in the form of rural populism, provides important comparative insights that can illuminate the Indonesian case. ${ }^{9}$ These comparative cases highlight the way oligarchic and plutocratic politics can be constrained by entrenched and organized social forces in quite different ways. The relative feebleness of such influences in Indonesia, in spite of the developments observed by Edward Aspinall and by Teri Caraway and Michele Ford, provides a particularly telling insight. ${ }^{10}$

\section{c) The "Matter of Time" Argument}

This theory does not assume that there will be linear progression from authoritarianism to a predatory form of democracy and then to a liberal form. In other words, we propose that there are clear limits to the utility of arguments regarding the

\footnotetext{
${ }^{6}$ S. N. Sangmpam, "Politics Rules: The False Primacy of Institutions in Developing Countries," Political Studies 55,1 (2007): 201-24.

${ }^{7}$ Hadiz, Localising Power in Post-Authoritarian Indonesia.

${ }^{8}$ In our various studies, we have brought in such cases as post-Soviet Russia, Egypt, and the broader Middle East. See Robison and Hadiz, Reorganising Power in Indonesia; Vedi Hadiz and Richard Robison, "Neo-Liberal Reforms and Tlliberal Consolidations: The Indonesian Paradox," Journal of Development Studies 41,2 (February 2005): 220-41; and Vedi R. Hadiz and Richard Robison, "Political Economy and Islamic Politics: Insights from the Indonesian Case," New Political Economy 17,2 (2012): 137-55.

${ }^{9}$ Winters, Oligarchy.

${ }^{10}$ Edward Aspinall, "Popular Agency and Interests in Indonesia's Democratic Transition and Consolidation," this volume; and Teri L. Caraway and Michele Ford, "Towards Issue-based Politics? Unions and Electoral Contests in Democratic Indonesia," paper presented at the workshop Beyond Oligarchy? Critical Exchanges on Accountability and Representation in Indonesia, University of Sydney, December 14-15, 2012.
} 
"growing pains of democracy." Indeed, the factors that historically made possible the transformation to liberal forms of democracy elsewhere are not easily transposed to Indonesia. These may be the result of a conjuncture of historical circumstances that will not be repeated. Given these distinctions, the question is not about whether Indonesia has "transitioned to democracy," or whether its democracy has now "consolidated," but instead asks what are the configurations of social and political power that are shaping the evolution of Indonesian democracy. The product may be a form of democracy that is anomalous to the idealized liberal democratic template but which may thrive nevertheless. As Patrick Chabal and Jean-Pascal Daloz have argued in the case of Africa, what appear to be highly dysfunctional and chaotic political systems may, indeed, be highly efficient in terms of guaranteeing the interests of specific groups. ${ }^{11}$ And the cases of Russia, China, and even Singapore, for example, suggest a range of models in which illiberal politics and capitalism can survive and flourish together over time.

\section{d) Exclusion of Non-Material Factors}

There is no suggestion in structural political economy that non-material factors are unimportant in shaping conflicts over power and the way state authority is exercised. As we shall see, the influences of ideas of nationalism, populism, and corporatism, for example, are integral to our understanding of the rise of oligarchy throughout the Sukarno and Suharto periods and of the ways in which oligarchy defended itself against liberal and social democratic critics. We do not, however, see material and nonmaterial factors as separate and independent-a matter of choice for participants or scholars-but rather as always being bound in complex relationships.

\section{e) Agency Trumps Structure}

It is not generally suggested in political economy approaches that individuals are powerless to resist structural imperatives. Individuals and organizations have room to move within the circumstances they inherit. The demise of the New Order and the advent of electoral democracy have clearly made possible the emergence of new players and widened alliances that influence politics in substantive ways. Nevertheless, the oligarchy thesis rejects the liberal pluralist idea that individuals may simply accumulate resources such as wealth, authority, status, media control, and so on by virtue of the voluntary exercise of individual skills, including that of leadership. ${ }^{12}$ Instead, it is argued that, in the Indonesian case, individuals invariably find themselves required to accommodate the logic of the existing power structure. The difficulties of operating outside this logic are illustrated by the fall from grace of such former reformers within the Democratic Party as Anas Urbaningrum and Andi Mallarangeng as well as in the case of the PKS previously mentioned. Even the swashbuckling reformer from Solo, Joko Widodo (Jokowi), has had to enter dubious alliances in his time as mayor of Solo and as a Jakarta gubernatorial candidate; the

\footnotetext{
${ }^{11}$ Patrick Chabal and Jean-Pascal Daloz, Africa Works: Disorder as Political Instrument (Oxford and Bloomington, IN: The International African Institute with James Currey, and Indiana University Press, 1999).

${ }^{12}$ See R. William Liddle, "Improving the Quality of Democracy in Indonesia: Toward a Theory of Action," this volume.
} 
gubernatorial campaign involved no less than accommodation with Gerindra, the political vehicle of former Suharto son-in-law, Prabowo Subianto.

\section{f) A Theory of Pessimism}

These disagreements over agency and structure have led to claims that the Robison-Hadiz thesis is inherently pessimistic about the prospects for progressive change in Indonesia. We will deal with this critique more thoroughly in the final part of this paper. Such claims of pessimism conflate the rejection of institutional or agency based explanations of change and transition in Indonesia with a larger rejection of the possibility of change itself.

\section{Critical Political Economy and Contending Theoretical Explanations}

The central claim of a critical political economy approach is not merely that economics and politics are interrelated but that conflicts over wealth and power are part of the same broad process of social change. ${ }^{13}$ The rise of new forms of production and property give rise to new forces and interests and to new conflicts over the rules that will govern markets on such issues as property rights, working conditions, the provision of public welfare and public goods. Such rules and the institutions of economic life are, if judged from the political economy perspective, not simply based on questions of efficiency but is also about power and how it is distributed. It is due to the way in which the distribution of economic power and the nature of the state itself is formed that different levels of political resources and economic leverage are constructed.

Thus, the central task of political economy analysis is to explain the forces and interests that are historically thrown up in the evolution of capitalism and how conflicts between these shape economic and political life and the institutions in which they operate. It is important in explaining the evolution of this configuration of power that capitalism in Indonesia has moved from a colonial agrarian export economy to a nationalist import-substitution industrialism and, finally, to an export-oriented resources and industrial system more closely integrated within the global market economy. Concern with these issues distinguishes structural political economy from the main contending theoretical explanations of social and political change in contemporary Indonesia.

Modernization theory has been perhaps the most pervasive influence in the study of Indonesia over several decades. In its classical version, it has conceived of a process of political development synonymous with progress toward democratic pluralism and regarded as the natural accompaniment of economic development. ${ }^{14}$ As $\mathrm{R}$. William Liddle argues, economic growth is positive for democracy in that it gives rise to a

\footnotetext{
${ }^{13}$ Some examples of this general approach to explaining social and political change include: Colin Leys, The Rise and Fall of Development Theory (Oxford: James Currey, 1996); and Kiren Aziz Chaudhry, The Price of Wealth: Economies and Institutions in the Middle East (Ithaca, NY, and London: Cornell University Press, 1997). Such approaches are not confined to developing economies. See Andrew Gamble, The Free Economy and the Strong State: The Politics of Thatcherism (London: Macmillan, 1994).

${ }^{14}$ See Gabriel Almond and Sidney Verba, The Civic Culture: Political Attitudes and Democracy in Five Nations (Princeton, NJ: Princeton University Press, 1963).
} 
progressive middle class that demands personal autonomy, freedom, rule of law, and participation. ${ }^{15}$ That such a flowering of middle class/civil society failed to eventuate in Indonesia, even where economic growth took place, was explained in the 1960s and 1970 s as a result of traditional culture's resistance to such a change, manifest in the consolidation of successive forms of despotic rule. Not surprisingly, a common point of reference was the feudal and hierarchical nature of Javanese court culture, the resilience of which was thought to lead to irrational political behavior that was not in conformity with the ideal type of Western liberal democracy. ${ }^{16}$

The apparent absence of democratizing agents was resolved in a different way in the work of Samuel Huntington, where the main marker of modernity shifted from pluralist politics and democratic culture to the institutionalization of state power and political order. ${ }^{17}$ The product of heightened Cold War anxieties, revisionist modernization theory placed great emphasis on political stability because disorder could open up opportunities exploitable by the Left. Reflecting such concerns, Emmerson ${ }^{18}$ and Liddle $^{19}$ thus pondered whether the alternative to New Order authoritarianism was descent into chaos. For Liddle, especially, the authoritarianism of Suharto appeared to underpin economic development, for he believed that the president's personal interest was to support policies that promoted growth via the macroeconomic reforms advanced by international development organizations, especially after the fall of international oil prices in the early $1980 \mathrm{~s}^{20}$

The appeal of this version of modernization theory was severely eroded, however, as Indonesia's economy almost collapsed as a result of the Asian Economic Crisis of 1997-98. The idea of authoritarianism as the spearhead of modernization rather than the expression of specific economic and social interests was undermined when Suharto initially attempted to resist the macroeconomic reforms insisted upon by the International Monetary Fund rather than rise above the interests of the powerful oligarchic alliance that had underpinned the regime, including not least those of the Suharto family itself. ${ }^{21}$

Interestingly, some facets of this version of modernization theory have reappeared in different guises within neoliberal political economy and economic neo-institutional approaches. Theorists within these camps had long argued that it is the very power of the state to intervene in markets that provides the conditions for the rise of the rent-

\footnotetext{
${ }^{15}$ Liddle, this volume

${ }^{16}$ A recent expression of this approach is found in Webber, who maintains that the greatest obstacle to Indonesia's successful transition to democracy is cultural in nature. He suggests, however, that the values and norms associated with Javanese feudal culture - which obfuscate corruption and abuse of powermay be on the verge of breaking down because Indonesia's electoral democracy forces leaders and parties to behave more accountably and rationally. See Douglas Webber, "Consolidated Patrimonial Democracy? Democratization in Post-Suharto Indonesia," Democratization 13,3 (2006): 396-420.

${ }^{17}$ Samuel Huntington, Political Order in Changing Societies (New Haven, CT: Yale University Press, 1968).

${ }^{18}$ Donald K. Emmerson, "The Bureaucracy in Political Context: Weakness in Strength," in Political Power and Communications in Indonesia, ed. Karl Jackson and Lucian W. Pye (Berkeley, CA, and London: University of California Press, 1980), pp. 104-5.

${ }^{19}$ R. William Liddle, "Development or Democracy," Far Eastern Economic Review 9 (November 1989), p. 23.

${ }^{20}$ R. William Liddle, "The Relative Autonomy of the Third World Politician: Soeharto and Indonesian Economic Development in Comparative Perspective," International Studies Quarterly 35 (1991): $403-27$.

${ }^{21}$ Robison and Rosser, "Surviving the Meltdown."
} 
seeking economy, preventing good policy made in the public interest, diverting scarce resources from productive investment, and strangling economic growth. ${ }^{22}$ However, neoliberals in the World Bank and elsewhere began to question the idea that simply dismantling the state would produce efficient markets and to embrace the idea that the successful transplanting of markets required a strong framework of regulatory institutions that could only be supplied by the state. ${ }^{23}$ Reminiscent of Huntingtonian concerns for political institutionalization, some neoliberals began to argue that benign authoritarian leadership could enforce free markets in the face of predatory officials and rent-seeking robber barons. ${ }^{24}$ Prominent neo-classical economist Deepak Lal proposed that "a courageous, ruthless, and perhaps undemocratic government is required to run roughshod over these newly created special interest groups." ${ }^{25}$ Such sentiments became the basis for the World Bank's growing attraction to the notion of rule by a corps of enlightened technocrats or persons who are somehow liberated from the pursuit of self-interest and thus able to see beyond short-term goals to the public interest." ${ }^{26}$

The residual influences of modernization theory, whether in its liberal pluralist or institutional, technocratic managerial versions, shape the way post-Suharto Indonesia is understood outside the political economy approach. While pluralists search among the middle classes and in the institutions of elections for signs of liberal transformation, neoliberals place the blame for growing disorganization and chaos on democracy itself and the opportunities it offers to self-seeking interests and predatory raiders. ${ }^{27}$

Other influences can also be seen in the application of the democratic transitions literature in Indonesia. ${ }^{28}$ With its origins in the analysis of political change in the Iberian Peninsula and Latin America in the 1970s and 1980s, democratic transitions

\footnotetext{
${ }^{22}$ Deepak Lal, The Poverty of Development Economics (London: Institute of Economic Affairs, 1983); James M. Buchanan and Gordon Tullock, The Calculus of Consent (Ann Arbor, MI: University of Michigan Press, 1962); Robert Bates, Markets and States in Tropical Africa (Berkeley, CA: University of California Press, 1981); and Mancur Olson, The Rise and Decline of Nation: Economic Growth, Stagflation, and Structural Rigidities (New Haven, CT: Yale University Press, 1982).

${ }^{23}$ World Bank, Indonesia: Developing Private Enterprise (Washington, DC: World Bank, 1991); World Bank, Managing Development: The Governance Dimension, discussion paper (Washington, DC: World Bank, 1991); World Bank, World Development Report, Building Institutions for Markets (Washington, DC: World Bank 2002); World Bank, Indonesia: Accelerating Recovery in Uncertain Times, report from the East Asia Poverty Reduction and Economics Management Unit, October 13, 2000.

${ }^{24}$ T. N. Srinivasan, Neo-classical Political Economy: The State and Economic Development (New Haven, CT: Economic Growth Center, Yale University, 1985).

${ }^{25}$ Lal, The Poverty of Development Economics, p. 33.

${ }^{26}$ Merle S. Grindle, "The New Political Economy: Positive Economics and Negative Politics," in Politics and Policy Making in Developing Countries, ed. Gerald M. Meier (San Francisco, CA: International Center for Economic Growth, 1991), pp. 41-67.

${ }^{27}$ See, for example, Ron Duncan and Ross McLeod, "The State and the Market in Democratic Indonesia," in Indonesia: Democracy and the Promise of Good Governance, ed. Ross McLeod and Andrew MacIntyre (Singapore: Institute of Southeast Asian Studies, 2007), pp. 73-92.

${ }^{28}$ R. William Liddle, Crafting Indonesian Democracy: International Conference toward Structural Reforms for Democratization in Indonesia: Problems and Prospects (Bandung: Penerbit Mizan, 2001); R. William Liddle, "Indonesia's Democratic Transition: Playing by the Rules," in The Architecture of Democracy: Constitutional Design, Conflict Management, and Democracy, ed. Andrew Reynolds (Oxford: Oxford University Press, 2002); Edward Aspinall, Opposing Suharto: Compromise, Resistance, and Regime Change in Indonesia (Stanford, CA: Stanford University Press, 2005); and Paul J. Carnegie, The Road from Authoritarianism to Democratization in Indonesia (Basingstoke: Palgrave Macmillan, 2010).
} 
theory was distinguished by its reassertion of the primacy of social agency in political analysis and the crafting of benign pacts following the demise of authoritarian regimes-pacts through which democratic institutions replete with new rules for politics can be forged. This theory also reasserts the proposition that institutions can shape social and political behavior, dismissing the necessity of social revolution or transformation as a precondition for democratic change. ${ }^{29}$

These themes became attractive to many Indonesian analysts who hoped that the post-Suharto era would ultimately produce benign and liberal outcomes even if those outcomes developed after an initial period of confusion. What they offered was the possibility that good decisions made by the right kind of individuals, able to rise above patrimonial politics, could somehow bypass the structural constraints to democratization and empower those who had been marginalized under the authoritarian New Order. ${ }^{30}$

It soon became clear, however, that Indonesian democratization had provided a lifeline to the oligarchs incubated and nurtured within the previous centralized system of authority and patronage. This was a democracy driven by money politics and in which competition between an array of predatory interests over the spoils of state power, institutions, and resources would take more chaotic forms than under the New Order. Political parties and parliaments were largely unencumbered by programs or ideologies, and certainly free of liberal policies, and only occasionally subject to the demands of broader social interests that remain largely disorganized.

As the democratic transitions problematic began to lose its luster, ${ }^{31}$ a new literature has begun to emerge that appears self-consciously to place emphasis on civil society movements and new developments in such arenas as organized labor. Initiated by labor, new waves of strike action have taken place in some localities, making use of opportunities provided by democratization, and to which the Indonesian press has devoted considerable attention. The point of such works is, again, to explore the possibly of social agency trumping structural constraints, although these studies are focused on local and grassroots organizations rather than on technocrats and political leaders. Some but not all of this discourse is influenced by the broad literature on social movements and contentious politics as put forward by Doug McAdams, Charles Tilly, and Sidney Tarrow. ${ }^{32}$ Writing on the Indonesian labor movement, Benny Hari Juliawan, for example, ponders whether Indonesia is becoming a "movement

${ }^{29}$ Guillermo O'Donnell, Philippe C. Schitter, and Laurence Whitehead, Transitions from Authoritarian Rule: Comparative Perspectives (Baltimore, MD, and London: Johns Hopkins University Press, 1986).

${ }^{30}$ See, for example, Gerry Van Klinken, "How a Democratic Deal Might be Struck," in Reformasi: Crisis and Change in Indonesia, ed. Arief Budiman, Barbara Hatley, and Damien Kingsbury (Melbourne: Monash Asia Institute, 1999), pp. 59-68.

${ }^{31}$ For the reasons, see Thomas Carothers, "The End of the Transition Paradigm," Journal of Democracy 13,1 (2002): 15-21.

${ }^{32}$ See, e.g., Doug McAdams, Charles Tilly, and Sidney Tarrow, Dynamics of Contention (Cambridge: Cambridge University Press, 2001). 
society" $^{\prime 33}$ - a concept borrowed from David Meyer and Tarrow's analysis of public protest in advanced industrial societies. ${ }^{34}$

Social movement theory has its parallels with political economy theory in that it places an emphasis on change as a process driven by conflicts among politically organized social interests. A central point of divergence separating these two perspectives, however, lies in the different ways of understanding the relationship between the state and social power. In the political economy view, the rise of a vigorous civil society historically requires not the shrinking of state power, but its consolidation in a form that provides the guarantees of civil rights and rule of law. ${ }^{35}$ In other words, incremental sniping at the margins by social movements and NGOs has limited effectiveness. Real change in Indonesia requires that state power itself be wrested from the hands of a reconstituted oligarchy whose authority is embedded in the enforcement of institutional and legal practices that are antithetical to liberal notions of society and markets.

\section{The Idea of Oligarchy and the Explanation of Power in Post-Authoritarian Indonesia}

How, then, does a political economy analysis and a thesis that is focused upon oligarchy explain the way power and authority are reconstructed in the wake of authoritarian regimes? A pluralist might look for individuals able to construct their own power resources as a result of a capacity for leadership. Institutional theorists will assess the design and capacity of institutions and the levels of efficient governance able to insulate technocratic authority from vested interests. Other social theorists may investigate the extent of social capital, identifying this resource as the basis for a vibrant civil society. Structural political economists, on the other hand, will look at the way social power and interest are forged and configured and how this configuration is organized politically.

The questions to be asked are to some degree suggested by the strikingly different ways that authoritarian regimes around the world have collapsed and been transformed into various forms of democracy over the past several decades. ${ }^{36}$ The fall of the Mubarak regime in Egypt, for example, raises the question of why Indonesia has not descended into the political chaos, or at least the gridlock, that has defined the Egyptian situation and why the threat of retreat into some variant of illiberal politics, whether Islamic or military, has not been a real possibility in the Indonesian case. Or why have there been no prolonged power struggles within the ruling political and social forces and their military allies and emerging business interests as occurred in Thailand? There, the political struggles that followed the economic crisis of 1997-98

\footnotetext{
${ }^{33}$ Benny Hari Juliawan, "Street-level Politics: Labour Protests in Post-authoritarian Indonesia," Journal of Contemporary Asia 41,3 (2011): 349-70.

${ }^{34}$ David Meyer and Sidney Tarrow, eds., The Social Movement Society: Contentious Politics for a New Century (Oxford: Rowman and Littlefield, 1998).

${ }^{35}$ See E. M. Wood, "The Uses and Abuses of Civil Society," The Socialist Register 26 (1990): 60-84.

${ }^{36}$ Clearly we do not intend to enter into any extended comparative analysis in the context of this paper.
} 
culminated in the victory of elected business politicians within a new form of nationalist and populist political alliance. ${ }^{37}$

What is required in the political economy approach is an investigation of the genesis of Indonesia's oligarchy and how its political relations with other social forces and interests evolved. Several propositions emerge. Most important is that we understand oligarchy and the political regimes it spawned not simply as political phenomena but recognize their social character. Thus, the Suharto regime can be seen as resting upon a broad system of oligarchic relations that had, in themselves, become the central glue for a social order and determined the way power and wealth were accumulated and allocated from Jakarta down to the regions and towns of Indonesia. Oligarchy's growing political coherence and social pervasiveness meant it was no longer dependent specifically upon the institutions of centralized authoritarian rule but could embrace and colonize both market capitalism and political democracy. It was able progressively to shed its reliance on the coercive power of military or security forces, at least compared to the extent that defined Mubarak's oligarchy, for example. ${ }^{38}$

A second factor that has shaped Indonesia's political economy since the fall of Suharto is the way the emerging oligarchy organized its political relations with other forces. It is important that the previous Sukarno and Suharto regimes had thoroughly disorganized and fragmented social and political organizations and ideologies that threatened their absolute ascendancy, whether these were based within the liberal middle class, a radical and working class, or even a reactionary Islamic petty bourgeoisie. This effective disruption of civil society was achieved not simply through repression by the security apparatus but also within a more complex corporatist cooption of the civil society organizations. So long as prosperity was increased, Indonesia's middle class embraced Suharto and failed to grasp liberal ideas with any enthusiasm. As a consequence, when the old regime fell, despite the initial enthusiasm and energy of reformist movements, those with the most potential to strengthen civil society have never been able to recover any substantial ideological or organizational cohesion or build a substantial social base.

At the same time, the answer to the Indonesian "puzzle" also lies in the fact that attempts by the IMF and other international financial institutions to enforce constraints on the politics of oligarchy by means of institutional reform following the financial and economic crises of 1997-98 have been limited. This is not because of a successful resistance to democracy or markets on the part of the oligarchs but because these now suited their needs and provided a framework within which they could consolidate their authority and economic power. Liberals and neoliberals were to search vainly for progressive forces to support technocratic rule or the broader scope of liberal democracy or to dismantle the tentacles of oligarchy throughout the public bureaucracy or in the new parliaments.

\footnotetext{
${ }^{37}$ Kevin Hewison, "Neo-liberalism and Domestic Capital: The Political Outcomes of the Economic Crisis in Thailand," The Journal of Development Studies 41,2 (2005): 310-30.

${ }^{38}$ Samer Soliman, The Autumn of Dictatorship: Fiscal Crisis and Political Change in Egypt under Mubarak (Stanford, CA: Stanford University Press, 2011), pp. 63-65.
} 


\section{Oligarchy and the Neoliberal Challenge}

How, then, did oligarchy embrace the market and the rules that defined it? Neoliberalism and oligarchy have had a long and complex relationship in Indonesia. The rise of Suharto in 1965 had been welcomed by Western governments, especially when the new regime appointed a team of Western-trained economists to key economic ministries and began to wind back the system of nationalist state capitalism established by former President Sukarno. ${ }^{39}$

Nevertheless, the relationship between the neoliberal reformers and the oligarchs was to become tense and sometimes hostile. Despite the moves to dismantle the "guided economy" of the Sukarno period, important aspects of state capitalism were retained. Many state corporations continued to control access to key sectors of the economy, including in transport and communication, banking, trade, electricity generation, mineral resources, and agriculture. In part, such state-owned behemoths as Bulog and Pertamina served the old agendas of economic nationalism and protected industrial development, stabilizing commodity prices and subsidizing strategic industries, notably in steel, petrochemicals, shipping, engineering, fabrication, and in the communications sector. ${ }^{40}$

In reality, the authority exercised by the state over state bank credit, import licenses, forestry and mining concessions, and government contracts and procurement increasingly became the basis of a vast system of patronage and favor. At one level, rents raised by such activities became important sources of funding for the military and other state bodies and for individual officials and their families. At the same time, they were to be the underpinnings of a substantial domestic class of capitalists and associated swarms of rentiers and "fixers." The most important of these capitalists were drawn from the ethnic Chinese community and included the leaders of business empires like those of Liem Sioe Liong and William Soerjadjaja. To a much lesser extent, indigenous Indonesian business groups also launched their business ventures as recipients of contracts and monopolies allocated by powerful patrons within the state. ${ }^{41}$

By the 1980s, those interests controlling the terminals of this system began to take a more oligarchic form as the families of powerful officials and military officers, no longer satisfied with simply collecting tolls, now directly entered the world of business in their own right as owners of capital and as shareholders. This metamorphosis of officials and politicians into a putative bourgeoisie has been a common feature in developing capitalist economies, especially in places where they emerged from engagement in various forms of state capitalism. ${ }^{42}$ In the case of Indonesia, the way was led by the president's family, which constructed a vast business empire that extended from banking, forestry, and agriculture to automobiles and petro-chemicals. Other families from the ranks of political leaders, state officials, and military officers followed, not only at the national level but in a pattern to be repeated down to the

\footnotetext{
${ }^{39}$ J. Panglaykim and K. D. Thomas, "The New Order and the Economy," Indonesia 3 (April 1967): 73-120.

${ }^{40}$ Richard Robison, Indonesia: The Rise of Capital (Sydney: Allen and Unwin, 1986).

${ }^{41}$ Ibid.

${ }^{42}$ Events in the Middle East have provided an insight into the rise of family business dynasties from political origins in that region. Much of the vitriol of reformers was directed at the venality of the sons and relatives of various dictators, including Gaddafi, Ben Ali, Hosni Mubarak, and Saddam Hussein.
} 
provinces and towns and involving the families of governors, bupatis, and local military commanders. ${ }^{43}$

At the same time, policies also became more directly the instruments by which oligarchic interest was enhanced. Legislation to reserve government contracts and procurement for domestic business, under regulations Keppres 10 and 14 in 1979 and 1980 , channelled vast amounts of state funds into the hands of the State Secretariat and its Team 10 and through the president's special fund, Banpres, for the same purposes. ${ }^{44}$ Among its beneficiaries were a growing and politically important group of indigenous (pribumi) business figures, many of whom, notably Aburizal Bakrie, have continued to be key business and political players to the present time. In other words, the system of oligarchy had increasingly become the defining framework within which political power and wealth in Indonesia were drawn together and in which a divergence of families and groups were encompassed. ${ }^{45}$

It is important that oligarchy sought to consolidate itself not by simply negating the rules of the market but by selectively exploiting and expropriating them. In some cases, the state sector and its lucrative monopolies, including in banking, power generation, and telecommunications, were dismantled and transferred into private hands. In particular, the deregulation of the finance sector enabled a dramatic inflow of global capital for domestic investors. The rapid establishment of private banks, with little regulatory control, enabled private conglomerates to mobilize vast new sources of private funding for their own enterprises. ${ }^{46}$

Organizations like the World Bank and their Indonesian technocratic allies had only limited influence over this runaway system of oligarchy, especially with Indonesia's economic growth surging ahead in the 1980s and 1990s. There were other constraints on neoliberal agendas from unlikely quarters. Western governments were unwilling to upset governments and forces that opened the doors to their investors and served their larger geostrategic interests, and which kept radical and reactionary threats at bay. And large Western corporate investors competed with each other to get a place at the table where huge infrastructure and resource projects figured as important prizes; these investors proved willing to enter into the murky politics of oligarchy in the process. When the edifice of highly leveraged growth came apart in 1997 and 1998, Western banks, contractors, and resource companies were deeply implicated in the practices and relationships at the heart of the crisis.

\footnotetext{
${ }^{43}$ Robison, Indonesia: The Rise of Capital.

${ }^{44}$ See Robison and Hadiz, Reorganising Power, pp. 58, 60. The amounts of state funds involved: US\$20 billion between 1980 and 1986. See Jeffrey Winters, Power in Motion: Capital Mobility and the Indonesian State (Ithaca, NY: Cornell University Press, 1996), pp. 151-64; and Robinson Pangaribuan, The Indonesian State Secretariat 1945-1993 (Perth: Asia Research Centre, 1995), pp. 35-41.

${ }^{45}$ See Robison and Hadiz, Reorganising Power, pp. 57, 60.

${ }^{46}$ Ibid., pp. 82-84.
} 


\section{Surviving the Crisis: How Economic Power Was Reorganized}

The long coalescence of authoritarian politics, market capitalism, and oligarchy appeared to come to a dramatic end with the Asian Financial Crisis of 1997-98, as Indonesia was plunged into a destructive economic collapse that exposed the real and fragile political underpinnings of its economic miracle. An economy that had enjoyed decades of growth was forced to submit to the humiliating demands for policy and institutional reform by the IMF as Indonesia confronted a crisis of public and private debt that paralyzed its financial and banking institutions and engulfed its major corporate conglomerates. ${ }^{47}$ While some neoliberal economists placed the blame for the crisis upon dysfunction in the global financial architecture, ${ }^{48}$ it was more widely accepted that Asian economies fell under the weight of their own inefficiency and the widespread cronyism that permeated the governments of the region. IMF managing director, Michel Camdessus, argued that the crisis resulted from Asian governments' and corporations' refusal to adhere to the disciplines of global markets and was a lesson for Asia's policy-makers and a "blessing in disguise" that would pave the way for better policy choices. ${ }^{49}$

The huge catalogue of demands set by the IMF as conditions for its US\$30 billion rescue package included stringent requirements for reforms in governance and rule of law, as well as transparency and disclosure of information that enabled prices and risks to be set at their true value. ${ }^{50}$ More immediately, the IMF set out plans for an extensive recapitalization of banks and debt repayment by Indonesia's struggling corporate moguls. ${ }^{51}$ Yet, the expectation that the bitter lessons of the crisis would be, in themselves, sufficient to change things failed to take into account the real factors that defined any social or economic order. As Pranab Bardhan has argued, the significance of crisis in bringing about real change lies not so much in the lessons it offers to improve efficiency but in the way crisis undermines existing political forces and enhances new and reformist ones. ${ }^{52}$ Because reforms are not simply about the efficiency of markets, but have real implications for the way power is distributed and how existing elites are sustained, such interests will resist reforms even where the economic costs are severe.

In the Indonesian case, attempts to close insolvent banks and to force insolvent groups to part with assets and repay debt have met with fierce resistance. This was not

\footnotetext{
${ }^{47}$ Ibid., pp. 6-10.

${ }^{48}$ Ross McLeod, "Indonesia," in East Asia in Crisis: From Being a Miracle to Needing One, ed. Ross McLeod and Ross Garnaut (London: Routledge, 1998), pp. 31-48; Ross Garnaut, "The Financial Crisis: A Watershed in Economic Thought about East Asia," Asian Pacific Economic Literature 12,1 (May 1998): 1-11; and Hal Hill, The Indonesian Economy in Crisis: Causes, Consequences, and Crises (Singapore: Institute of Southeast Asia Studies, 1999).

49 "Socialist International," editorial, Asian Wall Street Journal, December 18, 1997; "An \$18 Billion Inoculation," Asian Wall Street Journal, February 5, 1998.

${ }^{50}$ See Gary Hamilton, "Asian Business Networks in Transition: Or, What Alan Greenspan Does Not Know about the Asian Business Crisis," in The Politics of the Asian Economic Crisis, ed. T. J. Pempel (Ithaca, NY: Cornell University Press, 1999), p. 47.

${ }^{51}$ Robison and Hadiz, Reorganising Power, pp. 6-10.

${ }^{52}$ Pranab Bardhan, "The New Institutional Economics and Development Theory: A Brief Critical Assessment," World Development 17,9 (1989): 1389-95.
} 
only true in the dying days of the Suharto regime. ${ }^{53}$ Despite the starkness of the "lessons" of the financial crisis and the huge leverage of the IMF and other agencies in pressing for specific reforms in policy and governance, oligarchy and its major players were ultimately able to survive. The key to this "success" was the resilience of the networks of political authority and economic interest that underpinned and defined oligarchy and permeated the institutions of the state itself. Neoliberal reformers and their allies were never able politically to dismantle these.

One critical illustration of this failure to reform and uproot Indonesia's oligarchy can be found in the way the IMF program of bank recapitalization was carried out. Despite the fact that most of Indonesia's beleaguered and insolvent banks were revealed to have contravened capital adequacy provisions and the IMF's laws on intragroup lending, these institutions were provided with large injections of funds by Bank Indonesia in the form of so-called liquidity funds (BLBI, Bantuan Likuiditas Bank Indonesia) intended to enable the banks to remain liquid, but which, in reality, were often sent offshore immediately to prop up other parts of the corporate groups. While the establishment of IBRA (the Indonesian Bank Recapitalization Agency) was intended to secure the assets of the disabled banks to fund a government bailout, in reality it enabled many of the conglomerates to warehouse their assets, write down debts at inflated values assigned to assets, and, in some cases, to repurchase assets at much reduced prices. ${ }^{54}$

One of the reasons for this great escape was the continuing grip of oligarchy on the critical parts of the bureaucracy, including in many key financial ministries and in the judiciary and commercial courts, where the will to pursue corruptors and debtors was undermined as the central elements in the judiciary proved reluctant to convict corrupt political and business figures. ${ }^{55}$

Two of Indonesia's presidents, Abdurahman Wahid and now Susilo Bambang Yudhoyono, made the fight against corruption a central plank in their political programs. This struck a responsive chord with the public. The Corruption Eradication Commission (KPK, Komisi Pemberantasan Korupsi) was thus established and has been successful in bringing charges against a range of politicians and business figures that were not possible under the previous regime, although its reach remains limited. ${ }^{56}$ The investigations of non-government organizations, the KPK, and the media continue to provide detailed insights into the way politics and business continue to be inextricably entangled, as was shown in the spectacle that was the Bank Century case, which reached into the very heart of the Democratic Party, led by the president. This is a pattern that reaches from the heights of national politics and the most powerful corporate figures down into the arenas of provincial and subprovincial politics. ${ }^{57}$

\footnotetext{
${ }^{53}$ Robison and Rosser, "Surviving the Meltdown."

${ }^{54}$ Discussed in detail in Robison and Hadiz, Reorganising Power, pp. 187-222.

${ }^{55}$ Timothy Lindsey, "Black Letter, Black Market, and Bad Faith: Corruption and the Failure of Law Reform," in Indonesia in Transition: Social Aspects of Reformasi and Crisis, ed. Chris Manning and Pierre van Dierman (Singapore: Institute of Southeast Asian Studies, 2000), pp. 278-92.

${ }^{56}$ Simon Butt, Corruption and Law in Indonesia (London: Routledge, 2012).

${ }^{57}$ Hadiz, Localising Power in Post-Authoritarian Indonesia.
} 
It is significant that, despite the new leverage of reformers and regulatory institutions, oligarchy and its beneficiaries still operate openly. KPK continues to be pressured by powerful interests seeking to discredit its officials, and in some cases influential figures still appear to possess immunity from legal redress, as demonstrated in the case of Aburizal Bakrie. ${ }^{58}$

\section{Oligarchy and the Challenge of Liberal Politics}

Middle-class liberalism, with its emphasis on individual rights and rule of law, has been a slender but consistent thread in the political history of Indonesia. Through the political prominence of middle-class intellectuals and professionals, those advocating liberalism exercised an influence beyond its numbers in the brief period of parliamentary democracy in the 1950s. Student movements, sometimes involving street demonstrations, arrests, and imprisonment, continued to punctuate even the deepest periods of authoritarian rule under Suharto. Yet, middle-class liberalism was never translated into an effective or coherent force in Indonesia during authoritarian rule.

It is natural that authoritarian regimes are hostile to liberal political movements and ideas. In Indonesia, the particular corporatist and functionalist influences in authoritarian politics provided especially effective weapons in keeping civil society and liberal politics at bay. The notion of a single national interest embodied in the corporatist and populist ideals of both "guided democracy" and Suharto's development state denied the legitimacy of claims by liberals for political participation and representation outside the prescribed functionalist frameworks. ${ }^{59}$ In this Orwellian circumstance, there was no room for the incubation of the sort of progressive civil society and its independent institutions expected by liberal pluralists.

The disorganization of liberal politics was not reliant on repression. Rather, the cooption of the middle classes, including critics and more moderate opponents, was to be the primary means of defusing and domesticating potential opposition. For the middle class, access to patronage, jobs, and careers, and to the benefits of economic growth, came at the cost of accepting that the arena of politics was bounded by a single state ideology (Pancasila) and confined within a form of state-managed electoralism dominated by a state political party (Golkar) and smaller, approved political parties (PDI, Partai Demokrasi Indonesia, Indonesian Democratic Party; and PPP, Partai Persatuan Pembangunan, United Development Party).

At another level, it is critical that political liberalism was never able to become the ideological basis for wider alliances between the middle class and the bourgeoisie, while an emerging working class was largely separated from social democratic political traditions. ${ }^{60}$ Importantly, Indonesia's bourgeoisie had been formed in

\footnotetext{
${ }^{58}$ For example, one of his companies, Lapindo Brantas, is widely considered responsible for massive mudflows that have destroyed the ecology of a significant swath of East Java, as well as the homes and livelihoods of tens of thousands of ordinary people.

${ }^{59}$ David Bourchier, "Lineages of Organicist Political Thought in Indonesia" (PhD dissertation, Monash University, Melbourne, 1996); and David Reeve, Golkar of Indonesia: An Alternative to the Party System (Singapore: Oxford University Press, 1985).

${ }^{60}$ Vedi Hadiz, Workers and the State in New Order Indonesia (London: Routledge, 1997).
} 
circumstances where the state controlled the gateways through which private interests might enter the economy - the vast networks of licenses, monopolies, concessions, and contracts that provided access to resources, trades, and bank credit. It was an accommodation that suited Indonesia's bourgeoisie, providing a broad shelter for a bourgeoisie that was predominantly ethnic Chinese and therefore vulnerable to the threats of both social radicalism and reactionary populism so important in the $1950 \mathrm{~s}$ and 1960s. The political agenda of the Chinese bourgeoisie has always been to protect these arrangements and to develop close alliances and relationships with powerful officials and political power-holders rather than replacing them with open markets and transparent and general rules. ${ }^{61}$

It is important, too, that the social and political basis of the regime was changing. These changes were manifest, not least, in deepening struggles for control of the military, often depicted as conflicts between secular and "green" (Islamic) political factions, but, in reality, a conflict in which oligarchy had begun to assert its authority over the old institutions and interests of state capitalism and over the officials of Benedict Anderson's "state qua state." ${ }^{22}$ Oligarchy had, in fact, become constrained by state capitalism and economic nationalist policy as the public monopolies of state capitalism were progressively and selectively expropriated and transformed into private monopolies. However, it is significant that, in this drift towards a kind of market politics where money and oligarchic power were increasingly ascendant, the old authoritarian structures became less necessary.

When the Suharto regime collapsed, political liberals believed they were going to play a central role in deciding the way politics was to be reconstructed in Indonesia. The reformasi movement made strident demands for a new political era to be based on the classical liberal principles of individual rights and popular democracy. The World Bank, the IMF, and other international development organizations played a pivotal role in driving the new laws on politics and decentralization that were to define democratic politics and administrative authority after Suharto. However, the movement ultimately faded into a relatively uncoordinated series of mainly student actions sporadically connected with the activities of a small liberal intelligentsia. Compared with the middle-class liberals and their leftist allies subsequently involved in the Arab Spring, for example, the would-be Indonesian reformers were even more disorganized and bereft of a real political or social narrative.

In fact, those who might be considered the representatives of progressive liberalminded civil society have been pitched into a political arena defined by proliferating corruption and money politics and the rise of extra-legal forms of social and political violence and coercion. They were quickly marginalized in an ongoing struggle where a resurgent oligarchy was able to build new and more pervasive social and political alliances and settle comfortably into the new democratic ambience.

Despite their early efforts to impose institutional changes and subsequent attempts to prop up the reforms through various programs of capacity building, "good

\footnotetext{
${ }^{61}$ Robison, Indonesia: The Rise of Capital; Robison and Hadiz, Reorganising Power in Indonesia.

${ }^{62}$ Benedict Anderson, "Old State, New Society: Indonesia's New Order in Comparative Historical Perspective," Journal of Asian Studies 42,3 (1983): 477-96; Robison and Hadiz, Reorganising Power in Indonesia.
} 
governance," and democracy promotion, the international development organizations had limited influence over the course of change in Indonesia. In any case, neoliberals have always harbored suspicion of democracy as a form of government that could open the door to distributional coalitions and predatory raiders and frustrate the efficient workings of markets. ${ }^{63}$ Some neoliberal commentators have even looked back with some degree of nostalgia to the certainties that authoritarian rule provided to technocratic planners and investors alike. ${ }^{64}$

As a proliferation of political parties emerged to contest the elections, it was significant that no new parties emerged on the basis of liberal or social democratic ideas to seize the moment. The long-awaited presidency of Megawati failed to deliver on its claims to the populist legacy of Sukarnoism. Megawati's tenure was to be defined instead by policy failure and murky alliances with the military and business. Not surprisingly, parliaments and the political parties became widely regarded as major realms for corruption. The former state political party, Golkar, quickly became the home of many former leading figures of the Suharto era, even if some have migrated to other parties, including the Democratic Party. If there are any signs of something different, they come from the populist and xenophobic Right and from parties like Gerindra, led by Prabowo Subianto. In this context, the parallels with Thailand's Thaksin Shinawata and his fusion of populism and business interests are clear.

\section{Surviving Decentralization: How Local Power Was Reorganized}

Decentralization of government and administration has been long regarded by neoliberal policy makers, not least in the World Bank and the IMF, to be ideally suited to ensure government accountability and the liberation of individuals and businesses from stifling centralized control to enable them to be innovative and enterprising. At another level, populist NGOs have regarded decentralization as a path to the empowerment of local citizens and grassroots social organizations. ${ }^{65}$ There is no doubt that the decentralization of government and administration in Indonesia under Laws 22 and 25 of 1999 has been far-reaching. This so-called "big bang" of decentralization saw real administrative and financial authority shifted into the hands of regents (bupatis) and mayors and to local parliaments. ${ }^{66}$

These new institutional arrangements have enabled a vigorous electoral politics to emerge at these lower, regional levels and have allowed the expression of local opposition and demands in a way not possible before. Voters have proven willing to throw incumbents out of office if they displease them, and, in some cases, reformist mayors and bupatis have been elected even when they ran against the heavyweights of established parties and cliques. Some of these successful candidates have even made

\footnotetext{
${ }^{63}$ See James Dorn, "Economic Liberty and Democracy in East Asia," Orbis 37,4 (1993): 599-619; and F. A. Hayek, The Road to Serfdom (London: Routledge, 2001).

${ }^{64}$ Ron Duncan and Ross McLeod, "The State and the Market in Democratic Indonesia," in Indonesia: Democracy and the Promise of Good Governance, ed. Ross McLeod and Andrew MacIntyre (Singapore: Institute of Southeast Asian Studies, 2007), pp. 73-92.

${ }^{65}$ Hadiz, Localising Power in Post-Authoritarian Indonesia.

${ }^{66}$ Nankyung Choi, Local Politics in Indonesia: Pathways to Power (London: Routledge, 2011).
} 
progress in cleaning up moribund bureaucracies and cleaning out corrupt cliques and individuals. ${ }^{67}$ However, these accomplishments are not necessarily indicative of the early stages of a more general rise of progressive interests at the local level.

Moreover, Hadiz has argued that the decentralization of political and administrative institutions has more generally provided opportunities for the same kinds of social interests previously at the heart of Suharto's New Order to assert their power at the local level.$^{68}$ Thus, the vast majority of local parliamentary candidates, as well as individuals vying for positions as bupatis and mayors, have been drawn from a pool of former officials, party apparatchik, as well as business figures and gangsters, many of whom had helped to exercise authority at the local level on behalf of the old authoritarian regime. ${ }^{69}$ Even where reformist and progressive figures have emerged, they necessarily have had to make accommodation with entrenched political and economic forces and to operate within circumstances already in place. The point is that while the new institutions may have made some things newly possible, what really matters, at the local level as well as the national level, are the kinds of interests that are able to organize politically to influence and profit from the institutions.

\section{Conclusions: Where to Now?}

As we noted earlier, the oligarchy thesis has been criticized for an underlying pessimism about the prospects for social and political reform in Indonesia and for dismissing the significance of democratic transformation and of the efforts to reform public institutions. One source for these criticisms is to be found among pluralist scholars, including R. William Liddle and Thomas Pepinsky. ${ }^{70}$ For Liddle, the oligarchy thesis denies not only the possibility of progressive liberal transformation but also the possibility of individual agency in politics and of political action by individuals on behalf of democratic consolidation. In Liddle's view, politics operates in Machiavellian terms, so that the accumulation of power resources by individuals, such as wealth, position, and status, is achieved by astute strategic decisions, including decisions made when building political and economic alliances or capturing votes in elections.

Thomas Pepinsky argues that the oligarchy thesis cannot provide an account of the complexity of power struggles or the importance of non-material power resources, nor can it acknowledge and explain the sheer number or fluidity of elements that constitute the oligarchic system, which is often intent on survival rather than any enduring ideas or policy agendas. The theoretical key to the analysis of Indonesian politics lies, therefore, according to Pepinsky, in a form of critical pluralism that recognizes the fluid and shifting processes wherein coalitions are formed and dissolved according to

\footnotetext{
${ }^{67}$ Luky Djani, "Reform Movements and Local Politics in Indonesia" (PhD dissertation, Murdoch University, 2013).

${ }^{68}$ Hadiz, Localising Power in Post-Authoritarian Indonesia.

${ }^{69}$ Ibid., especially Chapter 4.

${ }^{70}$ See R. William Liddle, "Improving the Quality of Democracy in Indonesia," this volume; and Thomas Pepinsky, "Pluralism and Political Conflict in Indonesia," this volume.
} 
changing circumstances and based on interacting material and non-material resources, including that of identity.

A further criticism is that the oligarchy thesis underplays the importance of political conflicts taking place at the margins and within the lower orders of society, not least at the local level. Edward Aspinall, for example, points to the widespread rise of reformist movements and cites their-sometimes successful-demands for reforms in labor and in the provision of social safety nets and services in health and education, protection for the environment, the elimination of corruption, and so on. ${ }^{71}$ This evidence can be interpreted either as proof of a fundamental theoretical failure of the oligarchy thesis or, more simply, proof of the theory's adherents' failure to recognize and give proper weight to the importance of politics from below within the basic theoretical framework of the oligarchy thesis.

What is disputable from the structural political economy perspective is the larger transformative significance of these forms of oppositional politics. Such a concern can be illustrated if we imagine a circumstance-that the current oligarchy in Indonesia has disintegrated, due to internal fractures or perhaps in combination with another deep global economic crisis. In such a case, there would be no guarantee that an alternative form of rule could take its place, sustained by a set of coherently organized social interests. In other words, there could be a repeat of the situation that came about at the end of the Suharto era, when there was no reformist coalition ready to step into the temporary void before old interests reorganized, thus ensuring that the New Order legacy continues to this day. What set of circumstances, then, can break this cycle?

Our basic propositions are that real change cannot be achieved so long as the social order of the previous regime and its ascendant political forces remain intact and in charge of the state. Attempts to induce change by institutional fixes and programs of "good governance" cannot bypass the bitter and sometimes violent conflicts over power that historically accompany social and political transformation. Incremental demands for reform by individuals or groups can only be piecemeal if they do not achieve a broader political ascendancy and control over the state. This means that a transformation of substance, rather than a descent into chaos or simply more of the same, requires both the disintegration of the old order and its social underpinnings and the forging of a new social order with its political forces.

All this does not mean that Indonesia is necessarily caught in a state of permanent atrophy or that oligarchy is unassailable. Where, then, should we look for the potential sources of change? We propose that, rather than looking outside the broader system of oligarchy itself, to those attempting to bring it down, we should look within the framework of oligarchy, for that is where the dynamics of change are most likely to be forged. From the perspective of structural political economy theory, one potential source is generated as capitalism outgrows its predatory roots and where capital begins to see its interests in more predictable and transparent regulation and in rule of

\footnotetext{
${ }^{71}$ See Edward Aspinall, "Popular Agency and Interests in Indonesia's Democratic Transition and Consolidation," this volume. See also Edward Aspinall, Opposing Suharto: Compromise, Resistance, and Regime Change in Indonesia (Stanford, CA: Stanford University Press, 2005).
} 
law. ${ }^{72}$ In Indonesia, these tensions are shown in disputes over mining regulation, investments laws, and corporate governance (as revealed in the conflict over Bumi Plc, involving the Bakries and the Rothchilds). They are also crystallized in battles over the authority and reach of the KPK and other regulatory institutions, battles that take place with government and within the oligarchy itself.

However, there are difficulties here. One is that capital has historically been politically opportunist rather than reformist, reluctant to accept the risks of attaching itself to reformist politics. Indonesia's middle classes, too, have been incubated within the framework of the state and have shown little appetite for engaging in reformist opposition or for establishing political relationships with, for example, organized labor, as was sometimes the case in Europe. Invariably, the reform of capitalism has required the intervention of the state itself throughout history. And numerous systems of authoritarian rule and/or oligarchy have shown a remarkable resilience in the face of neoliberal policy and institutional reforms. ${ }^{73}$ Nor is there necessarily any fundamental disjuncture between illiberal politics and market capitalism. ${ }^{74}$ Waiting for the logic of the machine to drive reform may be a forlorn prospect. Singapore and China are only two examples of countries where successful capitalist economies can flourish within highly illiberal political systems.

It is also true that the growing reach of global governance over the rules of trade, investment, and public management is offset by the extensive relations that exist among various governments and oligarchies in the developing world with international investors and Western governments, relations that are important in sustaining those less developed states and their economies. ${ }^{75}$ International capitalists are often enthusiastic about the way authoritarianism can sweep away environmental, labor, and welfare coalitions and remove regulatory constraints on their commercial ambitions. For Western governments and international organizations, activities that involve them in the fortunes of oligarchies are often intermingled with strategies to preserve these special advantages for investors.

A second potential source of contradiction within an oligarchy can be found in the highly diffuse, decentralized, and corruption-ridden system of money politics that has emerged in Indonesia. Significantly, it is a system that may prove to be increasingly exclusionary as the cost of gaining access to the spoils of state power generally grows beyond the reach of all but a few. Maybe it is in this way that decentralization will ultimately reveal its true significance: by opening new sites of localized conflict caused by the failure of an oligarchic power structure to absorb properly the ambitions of the growing armies of apparatchiks, local fixers, entrepreneurs, and enforcers that it has assembled across the archipelago.

\footnotetext{
${ }^{72}$ See, for example, Paul D. Hutchcroft, Booty Capitalism: The Politics of Banking in The Philippines (Ithaca, NY: Cornell University Press, 1998). In this study, Hutchcroft provides an extensive overview of Weberian and other theories about the progression of capitalism and its implications for politics and administration.

${ }^{73}$ See, for example, Joshua Stacher, Adaptable Autocrats: Regime Power in Egypt and Syria (Stanford, CA:

Stanford University Press, 2012).

${ }^{74}$ Garry Rodan, Transparency and Authoritarian Rule in Southeast Asia: Singapore and Malaysia (London: RoutledgeCurzon, 2004).

${ }^{75}$ Mick Moore, "Political Underdevelopment: What Causes Bad Governance?," Public Management Review 3,3 (2000): 385-418.
} 
Our analysis concludes that for the cycle to be broken and a new social order put in place nothing less is required than a deeper social and political revolution, whether in liberal or other directions. 